\title{
IMBAS NEGATIF GLOBALISASI TERHADAP PENDIDIKAN DI INDONESIA
}

\author{
Yuliana Setyawati, Qori Septiani, Risky Aulia Ningrum \& Ratna Hidayah \\ Universitas Sebelas Maret Surakarta \\ yuliana.setyawati17@student.uns.ac.id
}

\begin{abstract}
Abstrak
Globalisasi bagaikan dua sisi pisau yang apabila digunakan secara bijak akan menimbulkan kemudahan dan apabila tidak hati-hati akan mempersulit diri sendiri. Globalisasi mempengaruhi semua bidang, salah satunya adalah bidang pendidikan. Pendidikan di Indonesia sendiri antara sebelum globalisasi masuk sangat berbeda dengan setelah globalisasi masuk. Globalisasi sendiri mulai tampak dan mulai ada sekitar 1000 dan 1500 M. Salah satu sebaran nilainya adalah bidang pendidikan. Namun, dengan adanya globalisasi menyebabkan beberapa perbedaan di sistem pendidikan. Misalnya pada komersialisasi pendidikan. Dampak negatif lain akibat globalisasi dalam bidang pendidikan yaitu pengelompokan status sosial, melemahnya kekuatan kontrol pendidikan oleh negara, menurunnya kualitas moral siswa, tergerusnya kebudayaan local, dan munculnya tradisi serba cepat. Tulisan ini bertujuan untuk mengetahui dampak negatif globalisasi di bidang pendidikan dengan metode kualitatif dengan jenis studi literatur dari beberapa jurnal penelitian dan buku yang relevan.
\end{abstract}

Kata kunci: Globalisasi, Pendidikan, Negatif

\begin{abstract}
Globalization is such as a two-sided knife which if used wisely will make easier and if not be careful it will make getting worse for yourself. Globalization affects all fields, one of the affection field is education. In Indonesia, education has 'different thing' before and after globalization entered in. Globalization began to appear and began to exist between 1000 and 1500 AD. One of the distributions values is in the field of education. However, with globalization it causes some differences in the education system. For example in commercialization education. Another negative impact due to globalization in the field of education is the grouping social status, weakening control power of education by the state, moral decline of students, the erosion of local culture, and the emergence of fast-paced traditions. This paper aims to find the negative impact of globalization in the field of education by using the qualitative method with literature study from several relevant research journals and books.
\end{abstract}

Keyword: Globalization, Education, Negative

\section{PENDAHULUAN}

Pada abad ke- 11 kehidupan di dunia kan semakin kompleks dan saling ketergantungan (interdependence) yang sering diasosiasiakan dengan lahirnya globalisasi. Mengacu dari hal tersebut, unsure yang timbul ari globalisasi yaitu hilangnya batas antar negara karena system informasi semakin terbuka, pasar bebeas, era liberalisasi, kerjasama regional dan global, serta pasar bebas (Muslam: 2011). Istilah globalisasi berasal dari kata globe dan ization yang memiliki arti peta bumi yang bulat. Istilah ini awalnya digunakan oleh Theodore Levit pada tahun
1985 yng digunakan dalam bidang politik ekonomi yang khususnya politik perdagangan bebas dan transasksi keuangan. Berdasarkan ssejarah ini, kemudian terdapat dasar munculnya globlisasi yaitu revolusi elektronik dan disintegrasi Negara-negara komunis. Kemudian kata globalisasi diambil dari kata global yang bermakna universal atau kesejagatan (Khasanah: 2019).

Secara umum, globalisasi merupakan segala proses yang mengarah pada penyatuan seluruh warga dunia menjadi sebuah kelompok masyarakat global. (Suryana: 2018). Globalisasi diawali 
dengan suatu gejala yang kemudian masuk suatu proses penyebaran dengan melibatkan saluran-saluran globalisasi yang dapat menembus dunia. Pada era globalisasi ini informasi informasi dapat tersebar dengan luasa dan cepat, serta berbagai belahan dunia dapat mengaksesnya dengan mudah. Globlisasi tidak hanya dapat memepercepat arus penyebaran informasi, tetapi dapat memperpendek jarak suatu tempat, dan dapat mendekatkan hubungan antar individu, antar bangsa, serta antar negara.

Menurut Suryana (2018), teradapat beberapa poin yang perlu diperhatikan dalam globalisasi antara lain globalisasi merupakan suatu proses meluasnya pengaruh budaya ke penjuru dunia. Globalisasi merupakan fenomena khusus dalam peradaban manusia menuju kehidupan masyarakat global. Derasanya arus globalisasi menyebabkan ruang, aktu, tempat semakin sempit. Kemundian globalisasi mendorong kemajuan dalam bidang transportasi, komunikasi, perekeonomian global. Globalisasi dalam aspek kehidupan dapat menyebabkan setiap bangsa menjadi bagian dari system nilai dunia.

Menurut Khasanah (2019), terdapat tanda-tanda kemunculan globalisasi dalam berbagai kehidupan, antara lain arus ide yang ditandai dengan semakin derasnya nilai baru yang masuk ke suatu Negara, arus etnik yang ditandai aanya mobilitas manusia yang tinggi, arus media yang ditandai dengan semakin kuatnya mobilitas informasi, arus keuangan yang ditandai dengan semakin tingginya mobiltas modal, investasi, sera arus teknologi yang ditandai adanya mobilitas teknlogi.

Indonesia sebagai Negara berkembang tidak dapat menutup diri dari adanya globalisasi karena adanya globalisasi sebagai proses menuju lingkup dunia. Era globalisasi ditandai dengan hilangnya sekat-sekat antar bangsa yang menjadi tantangan dan peluang bagi seluruh bangsa di dunia. Kunci sukses dalam ememneangkan globalisasi adalah sumber daya manusia yang berkualitas (Suryana: 2018).

Globalisasi yang berkembanga di setiap bangsa di penjuru dunia menimbulkan gagasan-gagasan baru di berbagai bidang dalam satu kepentingan global. Sebagai bagian dari masayraakat global, aspek kehidupan di Negara Indoneai juga turut terkena arus globalisasi. Perkembangan global telah memberikan dampak dalam segala aspek kehidupan, salah satunya dalam bidang pendidikan. Pendidikan merupakan proses pematangan hidup yang diharapkan manusia dapat memahami arti dan hakikat hidup serta menjalankan tugas kehidupan dengan benar sehingga fokus pendidikan diarahkan untuk mmebentuk kepribadian unggul yang menitiberatkan proses pematangan kualitas, hati, akhlak, logika, serta keimanan (Hermino: 2018). Menurut Muslam (2011), pendidikan merupakan proses yang berkaitan dengan suatu upaya mengembangkan diri seseorang mengenai beberapa aspek kehidupan seperti pandnagan hidup, sikap hidup, dan keterampilan hidup. Globalisasi telah menciptakan tatanan baru dalam kehidupan di bidang pendidikan.

Globalisasi memiliki peran dalam mewarnai dunia pendidikan. Namun, globalisasi pendidikan jangan hanya dipandang sangat baik karena globalisasi juga memiliki dampak negative (Suryana: 2018). Globalisasi tidak hanya membuka akses terbukanya pengetahuan yang semakin massif dan terjangkau, tetapi juga menimbulkan persaingan sumber daya manusia yang semakin meningkat. Pendidikan terkadang dimaknai secara sempit sebagai kesesuaian antara input dan output. Dengan adanya perekmbangan teknologiinformasi da komunikasi yang 
masif mengakibatkan kompleksitas tantangan dalam mengejar pendidikan yang berkualitas semakin meningkat (Hermino: 2018).

Menurut Muslam (2011), pendidikan berwawasan global dapat dikaji berdasarkan dua perspektif yaitu perspektif kurikuler dan perspektif reformasi. Pada perspektif kurikuler, pendidikan berwawasan global adala suatu proses pendidikan yang betujuan untuk mempersiapkan tenaga terdidik kelas menengah dan professional dengan meningkatkan kemampuan individu dalam masyarakat yang berkeitan dengan masyarakat dunia. Sedangkan pada persepektif reformasi, pendidikan berwawasan global adalah proses pendidikan yang dirancang untuk mempersiapkan peserta didik dengan kemampuan dasar intelektual dan tanggung jawab guna memasuki kehidupan yang bersifat sangat kompetitif dan dengan derajat saling saling bergantung antar bangsa yang tinggi. Globalisasi pendidikan mampu meningkatkan mut pendidikan di suatu Negara karena adanya keinginan dari setiap Negara untuk memiliki tigkat pendidikan yang berkualitas.

Pendidikan memiliki kaitan dengan globalisasi yang mana dituntut untuk memberikan respon yang lebih cermat dengan adanya perubahan-perubahan yang berlangsung dalam kehidupan masyarakat, khususnya di Indonesia (Subiyanto: 2019). Globalisasi tidak hanya memberikan dampak positif, tetapi juga memberikan dampak negatif terutama dalam bidang pendidikan (Suryana: 2018). Adanya dampak atau imbas negatif ini perlu diwaspadai dan disikapi dengan bijaksana. Untuk membentengi generasi muda dari pengaruh negatif globalisasi ini, tentunya melalui pendidikan. Namun, pendidikan saat ini mendpat tantangan yang besar terkait lahirnya globalisasi. Tantangan ataupun persoalan yang dihadapi pendidikan di Negara berkembang, termasuk Indonesia tentunya berbeda dengan negara-negara barat. Persoalan dan tantangan pendidikan yang ada di Indonesia berkeitan dengan falsafah dan budaya bangsa yang mana teori-teori Barat tentang pendidikan dan pembangunan tidaklah senantiasa bersifat universal, serta jiwa dan watak bangsa harus menjiwai system pendidikan itu sendiri (Muslam: 2011).

Untuk dapat mengatasi tantangan tersebut diperlukan sebuah rumusan dan kebijakan baru tentang pendidikan di era globalisasi (Muslam: 2011). Bangsa Indonesia harus selektif dalam memanfaatkan globalisasi khususnya dalam bidang pendidikan. Diharapkan semua pihak terkait dalam dunia pendidikan dapat memanfaatkan globalisasi dengan baik, mendampingi peserta didik dalam kegiatan belajar, serta menanamkan nilai-nilai luhur yang sesuai dengan nilai-nilai yang terkandung dalam Pancasila (Khasanah: 2019). Setiap nilai yang masuk hendaknya dapat disesuaikan dengan nilai-nilai luruh Pancasila untuk menjaga karakter bangsa Indonesia. Selain itu, dengan adanya globalisasi, pendidik dituntut untuk lebih professional dalam bidangnya dengan belajar dan bekerja secara maksimal sehingga krisis pendidikan dapat diminimalisir (Subiyanto: 2019). Apabila setiap komponen memahami kondisi ini, maka globalisasi pendidikan akan lebih memeiliki nilai kemanfaatan yang lebih besar. Untuk itu diperlukan sikap selektif, memperkuat jati diri dan identitas bangsa, serta memeprsiapkan diri sebaik mungkin dalam menghadapi era globalisasi khususnya dalam bidang pendidikan.

\section{METODE PENELITIAN}

Metode penelitian yang digunakan adalah penelitian kualitatif dengan jenis penelitian studi literasi. Studi literasi 
merupakan serangkaian kegiatan yang berkenaan dengan metode pengumpulan data pustaka, membaca, mencatat, serta mengelola bahan penelitian dengan mengumpulkan beberapa penelitian terdahulu untuk menjawab imbas negatif globalisasi terhadap pendidikan di Indonesia. studi literasi ini diperoleh dengan dari sumber pustaka berupa buku dan jurnal-jurnal yang relevan dengan penelitian (Melfiora). Data yang diperoleh dianalisis oleh penulis kemudian dituangkan ke dalam bab maupun sub-bab sehingga menjawab rumusan masalah.

\section{HASIL PENELITIAN DAN PEMBAHASAN Hasil Penelitian}

Adanya globalisasi yang masuk ke Indonesia sejak dahulu memberikan dampak baik positif maupun negatif dalam pendidikan di Indonesia. Dampak negatif globalisasi terhadap pendidikan di Indonesia diantaranya terciptanya komersialisasi pendidikan, masyarakat berkelompok berdasarkan status sosial untuk menikmati pendidikan berkualitas, lemahnya kekuatan kontrol pendidikan oleh negara, kebudayaan yang tidak sesuai dengan nilai-nilai ideologi negara masuk dengan peluang besar dan sistem pendidikan di indonesia menuju arah dalam sistem pendidikan nasional.

Selain itu adanya globalisasi pada bidang pendidikan berdampak negatif pada menurunnya kualitas moral siswasiswa, kesenjangan sosial semakin meningkat, kebudayaan lokal semakin hilang dan pudar, serta munculnya tradisi serba instan dan cepat.

Dalam pendidikan di indonesia globalisasi memberikan dampak negatif yang mengarah pada ketergantungan terhadap teknologi seperti komputer dan internet. Jika dilihat pada pendidikan di era globalisasi ini siswa maupun guru lebih banyak menggunakan teknologi seperti internet sebagai pendidikan.
Namun dalam penggunaan internet atau dunia maya ini dapat berpengaruh negatif terhadap pendidikan karena dengan adanya internet yang tersebar luas dapat mengakses materi namun juga terdapat mengakses hal-hal negatif seperti pornografi, kekerasan, rasisme dan lainlain.

\section{Pembahasan}

Menghadapi arus globalisasi diperlukan benteng yang kuat agar tetap berada pada jalan yang sesuai. Misalnya dalam pendidikan, globalisasi tentu membawa banyak pengaruh baik positif maupun negatif. Dalam perkembangan dunia pendidikan selalu ada perubahan perubahan baik dalam kurikulum, struktur dan jadwal waktu, materi, manajemen, fasilitas yang digunakan, dan lain sebagainya. Sebelum masuknya globalisasi, fasilitas misalya teknologi dalam pembelajaran masih jarang bahkan belum ditemui, tetapi sesudah masuknya globalisasi teknologi sudah menjadi bagian dalam pembelajaran. Dalam menghadapi abad ke-21, UNESCO (1996) merekomendasikan pendidikan yang berkelanjutan (seumur hidup) yang dilaksanakan berdasarkan empat pilar proses pembelajaran, yaitu : Learning to know (belajar untuk menguasai pengetahuan), learning to do (belajar untuk mengetahui keterampilan), learning to be (belajar untuk mengembangkan diri), dan Learning to live together (belajar untuk hidup bermasyarakat) melalui jurnal "The International Commission on Education for the Twenty First Century". Agar mampu mewujudkan empat pilar pendidikan di era globalisasi informasi sekarang ini, para guru sebagai agen pembelajaran perlu menguasai dan menerapkan teknologi Informasi dan Komunikasi dalam pembelajaran (Jamun: 2018).

Menurut Rosenberg (2001: 8), dengan berkembangnya penggunaan TIK 
ada beberapa pergeseran dalam proses pembelajaran yaitu:

1. Dari ruang kelas ke dimana dan kapan saja,

2. Dari kertas ke "on line" atau saluran,

3. Dari fasilitas fisik ke fasilitas jaringan kerja

Perbedaan-perbedaan tersebut juga terjadi dalam pendidikan Indonesia. Apalagi di masa pandemic Covid-19 yang masih melanda, pengaruh teknologi dalam pembelajaran sangat besar kenampakannya. Dahulu siswa belajar tatap muka secara langsung dengan guru, sekarang pembelajaran dilakukan melalui tatap maya. Hal ini sesuai dengan pendapat Rosenberg bahwa dengan berkembangnya penggunaan TIK ada beberapa pergeseran dalam proses pembelajaran yaitu dari ruang kelas ke dimana dan kapan saja. Dimana saja diartikan siswa dapat belajar walaupun di rumah, di jalan atau dimanapun karena sifatnya uang lebih fleksibel. Namun dalam penerapannya terdapa dampak negatif tentang pembelajaran tatap maya, menurut Sudibyo (dalam Jamun: 2018), E-learning yang dapat menyebabkan pengalihfungsian guru dan mengakibatkan guru jadi tersingkirkan, atau juga menyebabkan terciptanya individu yang bersifat individual karena system pembelajaran dapat dilakukan dengan hanya seorang diri. Bahkan dimungkinkan etika dan disiplin peserta didik susah atau sulit untuk diawasi dan dibina, sehingga lambat laun etika dan manusia khususnya para peserta didik akan menurun drastis, serta hakikat manusia yang utama yaiu sebagai makhluk sosial akan tergerus.

Penelitian terdahulu dari Mayeni, Syafti, dan Sefrinal (2019) mengenai dampak perkembangan teknologi menghasilkan data bahwa dampak negatif perkembangan teknologi salah satunya adalah rendahnya nilai karakter terutama dari kehidupan sosial, kurangnya komunikasi siswa dengan lingkungan sekitar, rendahnya tingkat kepedulian sesama, perkembangan teknologi disalah gunakan untuk permainan yang membuat lupa diri. Namun sebelum mengenal teknologi secara masif, antara guru dan siswa masih ditemui komunikasi yang intens misalnya saat di sekolah. Sehingga dampak negative mengenai kurangnya komunikasi dapat dicegah.

Pendidikan di Indonesia sebelum globalisasi belum tampak adanya komersialisasi pendidikan karena pada waktu itu kebanyakan sekolah negeri dikelola oleh pemerintah Tidak seperti sekarang, banyak sekolah-sekolah swasta yang berlomba-lomba dalam fasilitas untuk menarik orang tua agar menyekolahkan anaknya disana (Nurgiansah, 2021). Sehingga pendidikan tidak lagi sama dan merata. Pendidikan diibaratkan sebagai pasar, anak-anak dengan ekonomi tinggi bebas memilih ingin bersekolah dimana sedangkan anak-anak dengan kemampuan ekonomi rendah hanya bisa gigit jari. Menurut Andrias Harefa (dalam Efferi: 2015), sisi negatif pendidikan di era globalisasi saat ini telah terjebak dalam arus kapitalisasi yang dalam istilah lain bernama komersialisasi pendidikan. Adanya biaya pendidikan yang tidak murah berakibat pada banyaknya anak yang berasal dari kelas ekonomi bawah sulit mendapatkan akses pendidikan yang lebih bermutu. Sekolah kemudian menerapkan aturan seperti pasar yang berimplikasi pada fisiologis pendidikan yang salah. Keberhasilan pendidikan hanya didasari pada besarnya jumlah lulusan sekolah yang dapat diserap oleh sektor industri. Pendidikan semacam ini tidak untuk menjadikan manusia-manusia melek sosial, padahal sebetulnya tujuan pendidikan untuk mengembangkan intelektual yang ada pada siswa. 
Beberapa perbedaan tersebut hendaknya dapat dijadikan pertimbangan sebagai benteng untuk menghadapi arus globalisasi yang semakin pesat, utamanya bidang pendidikan.

Globalisasi sering diterjemahkan "mendunia". Suatu entitas, betapapun, dimanapun, kapanpun, dengan cepat menyebar ke seluruh pelosok dunia, baik berupa ide, gagasan, data, informasi, produksi, pembangunan, pemberontakan, dan sebagainya, begitu disampaikan, saat itu pula diketahui oleh semua orang di dunia (Mustari \& Rahman: 2014). Dalam bidang ekonomi, globalisasi ekonomi berarti terintegrasinya ekonomi nasional ke dalam ekonomi dunia atau global. Bila dikaitkan dalam bidang pendidikan, globalisasi pendidikan berarti terintegrasinya pendidikan nasional ke dalam pendidikan dunia (Lestari: 2018).

Globalisasi ini masuk dengan mudah kesetiap Negara, begitupun dengan Indonesia. Pada saat ini dapat kita lihat berbagai hal yang terpengaruh atau bersumber dari kemajuan globalisasi ini. Khususnya pada bidang teknologi, saat ini Indonesia menjadi salah satu Negara pengguna internet terbesar di dunia (Amelia \& Dewi: 2021).

Proses globalisasi berlangsung melalui dua dimensi, yaitu dimensi ruang dan waktu. Globalisasi berlangsung di semua bidang kehidupan seperti bidang ideologi, politik, ekonomi, dan terutama pada bidang pendidikan. Teknologi informasi dan komunikasi adalah faktor pendukung utama dalam globalisasi. Dewasa ini, teknologi informasi dan komunikasi berkembang pesat dengan berbagai bentuk dan kepentingan dapat tersebar luas ke seluruh dunia. Oleh karena itu globalisasi tidak dapat dihindari kehadirannya, terutama dalam bidang pendidikan (Alwi: 2019). Globalisasi ini akan terus berkembang sesuai dengan perkembangan kehidupan manusia, karena globalisasi merupakan salah satu bagian dari proses kehidupan manusia. Perkembangan teknologi informasi dan komunikasi inilah sebagai salah satu faktor yang mempercepat globalisasi. Globalisasi berkembang diseluruh tatanan masyarakat, baik masyarakat kota dan masyarakat desa (Listiana; 2021).

Perkembangan dunia pendidikan di Indonesia tidak dapat dilepaskan dari pengaruh perkembangan globalisasi, di mana ilmu pengetahuan dan teknologi berkembang pesat. Era pasar bebas juga merupakan tantangan bagi dunia pendidikan Indonesia, karena terbuka peluang lembaga pendidikan dan tenaga pendidik dari mancanegara masuk ke Indonesia (Alwi :2019). Bila ditelusuri perkembangan globalisasi telah tampak dan mulai ada sekitar 1000 dan 1500 M. Saat itu ditandai dengan adanya interaksi dalam hubungan antar bangsa di dunia, mulai dari para pedagang melalui jalur darat maupun jalur laut. Para pedagang selain melakukan perdagangan mereka juga menyebarkan nilai-nilai agama, nilainilai sosial, seni, dan pendidikan.

Adanya globalisasi tentu membawa dampak bagi kehidupan dengan berhasilnya masuk dan mengubah berbagai aspek. Salah satu aspek yang berhasil di ubah dengan adanya globalisasi yaitu pada bidang pendidikan. globalisasi memberikan dampak dua dampak yaitu dampak positif dan dampak negatif dalam pendidikan. Menurut Listiana (2021) dampak positifnya dengan adanya globalisasi ini dimana teknologi sudah semakin maju dan berkembang, para pendidik menjadi semakin kreatif karena sudah memanfaatkan teknologi, yaitu internet dan komputer. Tidak seperti jaman dahulu yang masih menggunakan kapur dan papan tulis sebagai bahan untuk mengajar, sekarang sudah ada teknologi yang dapat memungkinkan kita untuk membuat berbagai bahan 
ajar yang beragam, salah satunya adalah dengan power point (Nurgiansah, 2020). Sekarang ini, dengan adanya teknologi memungkinkan kita untuk membuat tulisan, film, suara, music, gambar, dapat digabungkan menjadi satu untuk proses belajar.

Selain memberikan dampak positif, globalisasi juga memberikan dampak negatif dalam bidang pendidikan (Suryana, 2018). Menurut Khasanah (2019), dampak atau imbas negatif globalisasi dalam bidang pendidikan, antara lain :

1. Terciptanya komersialisasi pendidikan

2. Masyarakat dikelompokan berdasarkan status sosial untuk menikmati pendidikan berkualitas.

3. Lemahnya kekuatan kontrol pendidikan oleh negara

4. Adanya peluang yang besar masuknya kebudayaan yang tidak sesuai dengan nilai-nilai ideology negara.

5. Menjadikan sistem pendidikan negara lain sebagai arahan dalam penentuan sistem pendidikan nasional.

Sedangkan menurut Saodah (2020), terdapat beberapa dampak negatif yang globalisasi terhadap pendidikan, antara lain:

1. Menurunnya kualitas moral siswa

Informasi dari internet yang dapat diakses secara mudah dapat mempengaruhi moral siswa, contohnya situs-situs pornografi atau situs yang tidak pantas lainnya sangat mudah diakses di media sosial tanpa adanya filterisasi. Hal ini dapat mempengaruhi perilaku siswa baik secara langsung atau tidak langsung.

2. Meningkatnya kesenjangan sosial

Kemajuan teknologi dan informasi dalam dunia pendidikan perlu diimbangi dengan kesiapan mental dan modal yang tidak sedikit. Di negara berkembang seperti Indonesia perkembangan teknologi hanya dapat dinikmati sekolah-sekolah di wilayah perkotaan. Sedangkan sekolah yang berada di wilayah pedalaman terus tertinggal karena sulitnya akses dan kurangnya modal.

3. Tergerusnya kebudayaan lokal

Akibat adanya arus globalisasi ini, budaya di Indonesia dapat hilang seperti pudarnya rasa nasionalisme, berkurangnya sifat kekeluargaan, serta gaya hidup masyarakat yang kebaratbaratan.

4. Munculnya tradisi serba cepat dan instan

Orientasi pendidikan yang awalnya menekankan pada proses berubah menjadi ranah pencapain hasil. Hal ini mengakibatkan banyak orang yang hanya menekankan pada hasil akhir ketika menempuh sebuah pendidikan, bahkan saat ini makin marak adanya jual beli ijazah palsu karena banyak orang yang ingin cepat mendapatkan keuntungan secara cepat dan instan.

Menurut Salim (2014), terdapat beberapa dampak negatif globalisasi terhadap pendidikan, antara lain komersialisasi pendidikan dengan banyaknya didirikan sekolah-sekolah dengan tujuan utama sebagai media bisnis. Bahaya Dunia Maya dengan berbagai macam materi yang berpengaruh negatif beredar luas di internet seperti pornografi, kekerasan, rasisme, dan lain sebagainya. Kemudian ketergantungan, dengan adanya teknologi speerti komputer dan internet dapat menyebabkan kecanduan pada siswa maupun guru yang mana keduanya merasa tidak bersemangat jika dalam proses pembelajaran tidak menggunakan teknologi tersebut.

Sedangkan menurut Dewi (2019), globalisasi telah melahirkan masyarakat struktur industrial yang mana setiap individu dalam masyarakat dianggap 
sebagai bagian dari sistem suatu produksi. Jacob (dalam Dewi, 2019) menandai ciriciri masyarakat industri yaitu mentalitas teknologis, diskriminasi ilmu, pola pikir dan budaya hedonism serta materialistis, komersialisasi pendidikan, memudarnya kebersamaan, serta memperburuk kualitas sumber daya manusia sebagai pemimpin di masa depan.

Pertama mentalitas tekonologi yaitu keadaan masyarakat yang memiliki kepercayaan berlebihan terhadap teknologi, sehingga membentuk masyarakat dengan perilaku seperti mesin karena dalam pendidikan mereka dilatih dengan pola kerja mesin. Kedua diskriminasi ilmu yaitu masyarakat lebih respek dengan ilmu eksakta dan teknik dibandingkan dengan ilmu-ilmu humaniora. Ketiga pola pikir dan budaya hedonism serta materialistis, yaitu pandangan pola pikir masyarakat yang lebih kepada kemajuan ekonomi. Keempat komersialisasi pendidikan yaitu yang membutuhkan pendanaan yang mahal yang mana mutu lembaga pendidikan tidak lagi dinilai dari segi kualitas melainkan dari segi kuantitas. Kelima memudarnya kebersamaan yang mana lebih berorientasi pada individualistic personality. Keenam memperburuk kualitas sumber daya manusia sebagai pemimpin di masa depan yang mana lembaga pendidikan kehilangan budaya akademik yang telah menajdi budaya ekonomis dengan menerima calon siswa yang lebih kaya dengan IQ pas-pasan dibandingkan dengan siswa dengan IQ tinggi tetapi terpinggirkan karena miskin.

Dari beberapa hal tersebut dapat mengakibatkan krisis nilai dalam dunia pendidikan yang mana dapat berdampak buruk atau negatif terhadap dunia pendidikan. Agar globalisasi tidak memebrikan imbas atau dampak negatif yang terlalu besar dalam dunia pendidikan tentunya perlu adanya reorientasi pendidikan untuk kedepannya untuk mencerdasakan keshidupan bangsa (Salim, 2014).

\section{KESIMPULAN}

Pendidikan dalam perkembangannya tidak dapat lepas dari pengaruh perkembangan globalisasi, di mana ilmu pengetahuan dan teknologi berkembang pesat. Perkembangan globalisasi telah tampak dan mulai ada sekitar 1000 dan 1500 M. Saat itu ditandai dengan adanya interaksi dalam hubungan antar bangsa di dunia, mulai dari para pedagang melalui jalur darat maupun jalur laut. Para pedagang selain melakukan perdagangan mereka juga menyebarkan nilai-nilai agama, nilai-nilai sosial, seni, dan pendidikan. Sistem pendidikan di era dahulu dengan era globalisasi sangat berbeda, misalnya saja pada pembelajaran. Jika dahulu dilakukan secara tatap muka maka sekarang pembelajaran bisa dilakukan dengan tatap maya dimanapun berada. Hal ini mengakibatkan kurangnya komunikasi antara guru dan siswa. Imbas negatif dari globalisasi di bidang pendidikan lainnya yaitu pengelompokan status sosial, melemahnya kekuatan kontrol pendidikan oleh negara, menurunnya kualitas moral siswa, tergerusnya kebudayaan local, dan munculnya tradisi serba cepat.

Sebagai warga negara Indonesia yang kental akan budaya, sudah seharusnya kita menyaring hal-hal yang masuk. Karena jika tidak dapat menggerus budaya local yang sudah ada. Karena tidak semua budaya luar itu cocok dengan budaya kita. Saran bagi penulisan selanjutnya semoga dapat lebih divariasikan sumber dan topic pembahasan agar semakin menarik. 


\section{DAFTAR PUSTAKA}

Alwi. (2019). Dampak Globalisasi Terhadap Pendidikan Sekolah Dasar Negeri 2 Gu. Jurnal Akademik FKIP Unidayan, 7(2). From: https://hukum.unidayan.ac.id/index.php/IFKIP/article/view/84

Amelia, R. F., \& Dewi, D. A. (2021). Pentingnya Pendidikan Kewarganegaraan Dalam Meminimalisir Pengaruh Globalisasi Terhadap Karakter Cinta Tanah Air Pada Siswa SMAN 1 Majalaya. Ensiklopedia of Journal,3(3), 103-110. From: http://jurnal.ensiklopediaku.org/ojs-2.4.83/index.php/ensiklopedia/article/view/737/673

Dewi, E. (2019). Potret Pendidikan di Era Globalisasi: Teknosentrisme dan Proses Dehumanisasi. Sukma : Jurnal Pendidikan, 3(1). From: https://jurnalsukma.org/index.php/sukma/article/view/03105.2019/51

Efferi, A. (2015). Mengelola Lembaga Pendidikan di Era Global (Pergeseran Paradigma Humanis Menjadi Bisnis). Jurnal Pendidikan Islam, 3(1), 1-19. From: https://journal.iainkudus.ac.id/index.php/Quality/article/viewFile/1170/1071

Hermino, A, 2018, Guru dalam Tantangan Globalisasi: Kajian Teoritis dan Praktis dalam Manajemen Pendidikan, Yogyakarta: Ar-Ruzz Media.

Jamun, Y. M. (2018). Dampak Teknologi Terhadap Pendidikan. Jurnal Pendidikan dan Kebudayaan Missio, 10(1), 48-52. From: http://webcache.googleusercontent.com/search?q=cache:NXPwfMIbs8AJ:unikastpaul us.ac.id/jurnal/index.php/jpkm/article/view/54+\&cd=2\&hl=en\&ct=clnk\&gl=id

Khasanah, N, 2019, Globalisasi dan Gejalanya, Klaten : Cempaka Putih.

Lestari, S. (2018). Peran teknologi dalam pendidikan di era globalisasi. Edureligia: Jurnal Pendidikan Agama Islam,2(2), 94-100. From: https://www.ejournal.unuja.ac.id/index.php/edureligia/article/view/459/319

Listiana, Y. R. (2021). Dampak Globalisasi Terhadap Karakter Peserta Didik dan Kualitas Pendidikan di Indonesia. Jurnal Pendidikan Tambusai,5(1), 1544-1550. From: http://www.jptam.org/index.php/jptam/article/view/1134/1017

Mayeni, R., O. Syafti, dan Sefrinal. (2019). Dampak Perkembangan Teknologi Dikalangan Remaja Dilihat dari Nilai-Nilai Karakter. Turast: Jurnal Penelitian dan Pengabdian, 7(2), 239-246.From: https://doi.org/10.15548/turast.v7i2.1298

Melfiora. Penulisan karya tulis ilmiah dengan studi literature. UPT Balai penyuluhan pertanian pekanbaru.

Muslam. (2011). Globalisasi dalam pendidikan (desain kurikulum yang harus dikembangkan dalam pendidikan di era globalisasi). Jurnal wahana akademika,12.

Mustari, M., \& Rahman, M. T. 2014, Manajemen pendidikan, Jakarta: Raja grafika persada

Nurgiansah, T. H. (2020). Filsafat Pendidikan. In Banyumas: CV Pena Persada.

Nurgiansah, T. H. (2021). Pendidikan Pancasila. In Solok: CV Mitra Cendekia Media.

Salim, K., dan Mira Puspa Sari. (2014). Pengaruh Globalisasi Terhadap Dunia Pendidikan. From: https://www.researchgate.net/profile/Kalbin-

Salim/publication/271205216 PENGARUH GLOBALISASI TERHADAP DUNIA PENDI DIKAN Oleh/links/54c13b640cf2d03405c502c8/PENGARUH-GLOBALISASITERHADAP-DUNIA-PENDIDIKAN-Oleh.pdf

Saodah, dkk. (2020). Pengaruh Globalisasi Terhadap Siswa Sekolah Dasar. Pandawa: Jurnal Pendidikan dan Dakwah, 2(3). From: https://ejournal.stitpn.ac.id/index.php/pandawa/article/view/907/626 Subiyanto. (2019). Globalisasi dan pendidikan global. Jurnal transformasi, 15(2). 
Suryana, Y, dkk, 2018, Globalisasi. Klaten: Cempaka Putih.

Suryana,Y.,dkk, 2018, Ensiklopedia Pendidikan Pancasila dan Kewarganegaraan : Globalisasi, Klaten: Cempaka Putih. 